\title{
Some Fundamental Considerations for Educational Research with and in Developing Countries
}

\author{
Dietrich Goldschmidt
}

\section{The Oneness of the World and the Multiplicity of Ethnic and/or National Traditions}

I begin by pointing to a fundamental issue relevant to research in Third World countries which is carried out by people from the industrialised world. Today we experience the mutual interdependence of peoples from all parts of the globe, the oneness of the world; at the same time each of the peoples is concerned to preserve its uniqueness or, as it is called, its identity. Indeed, 'spaceship earth' carries many nations. However, all well known recent analyses - such as C. F. von Weizsäcker's The Politics of Perils: economics; society and the prevention of war (1978), the two reports by the Brandt Commission (1980, 1983), and the American Government Reports, Global 2000 (1980) and Global Future (1981) - deal with the question of identity only in rather general, sometimes contradictory terms.

They do not really examine the variety or the internal heterogeneity of these cultures, that exist under the veneer of technological civilisation. Apparently considering survival strategies only a matter of recommending measures to combat hunger, sickness, and ignorance, and to stop the plundering of our planet before it becomes irreparable, they make no suggestions for the social and psychological internalisation of external political, economic, technological, cultural, and - on a different basis - military effects on the countries of the Third World.

Von Weizsäcker, an outstanding scholar in the fields both of nuclear physics and philosophy, seeks to promote the idea of an international domestic policy - that is to say, a world policy developed through international institutions, which would include placing significant limitations on the sovereignty of the great powers. He believes that with victory over war itself, such a policy, while retaining a thoroughly pluralistic international system, could lead to a world order governed by reason.
In this effort to show Pathways through Jeopardy, as would be the exact translation of his 1976 collection of essays, von Weizsäcker concentrates on the material problems of human existence, the interrelatedness of what he calls technological civilisation with economic and political developments, as well as on the changes in out look indispensable to solving these problems. By emphasising the possibility that world culture as historically constituted is capable of further development, he also points to a perspective which transcends purely material interests, and indeed provides their basis.

He criticises what he terms the 'technological civilisation' which has 'today triumphed worldwide' and which, as he sees it, is the 'logical consequence of the central motive of modern Western culture'. He writes: 'The automat ism of technological civilisation in its forward motion is the automatism caused by training will and rationality of action at the expense of reason. We accumulate means without a thought to integrative ends' [1976:256]. Traditional bases of culture seem to have lost their authority. Von Weizsäcker speaks of the 'decay of our culture' evident in unbridled egoism, in the pursuit of material possessions, in ungovernability and similar phenomena. He recognises at the same time that the legitimacy of traditional values has been shaken to the core. Thus, he is sympathetic with attempts, particularly on the part of youth, to break out of existing conditions.

Willi Brandt, in the introduction to his first report [1980], points out that 'it is cultural identity that lends men dignity', so that for him the preservation of cultural identity and independence are crucial, especially during the process of technological modernisation. $\mathrm{He}$ warns against 'cultural imperialism', while at the same time proposing a catalogue of legal, social and economic principles, the promulgation of which in the battle against hunger and poverty would require a 'technologically based world civilisation' and which would certainly lead to 
an unavoidable complication of adjustment processes, if they were to be followed. Yet, Brandt states that 'it is imperative to find a balance between the chances offered by modern technology and the existence of individual peoples and regions which do not want to, and must not, lose their individuality. The solutions to these problems cannot be uniform' [1980:35]. Brandt, however, does not attempt to define the key phrase 'cultural identity', which by now has become virtually a slogan. We will return to this point later.

The October 1980 report to the President of the United States, Global 2000, represents a meaningful supplement to the works of von Weizsäcker and the Brandt Commission in pointing out the importance of global interconnections and dangers. Willi Brandt speaks of the 'globalisation of dangers and challenges', and agrees with Weizsäcker that some manner of world domestic policy must be developed [1976:27]. The volume, Global Future, the successor to Global 2000 , leaves no doubt of this position. It argues for example that it is not just a moral question for the United States, but very much in its interest as well, to contribute significantly more than it has yet contributed towards the elimination of inequality between rich and poor [1980:XIII f] - and, one must unfortunately add, than it has under its current president. We may speak of 'one world' today, but certainly not in that optimistic naïvety peculiar to some Americans who perhaps see themselves in the role of global helmsmen. Nor are we speaking of some 'myth' which could be objected to by such political critics as Ralf Dahrendorf [1980].

V. S. Naipaul's designation of India as a 'wounded civilisation' [1977] - a phrase we will come back to -can also be applied generally to the weaknesses of the present cultural situation. Von Weizsäcker puts his hopes in a change of thinking which would require us to 'transform our feelings of solidarity and justice into reason' [1976:260]. He ventures thus far, while expressly dispensing with any theory of culture. In his survey of the world situation, he then offers a few general statements which show clearly that here the limits of analysis and conceptualisation have been reached. On the one side, he foresees the possibility of overcoming war 'on condition that historically constituted human culture continues to develop and is not destroyed' (p261). On the other side, we may well ask what this human culture entails, for, as he says, 'the cultural assimilation of all parts of the world is now underway. . . A world state [would however] endanger freedom and promote cultural levelling' (p263). Thus, even in Weizsäcker, a great deal remains unresolved

Scientific and technological civilisation does indeed represent something like a world culture. It overlays the older, regional Third World cultures with its language, its social norms, its rationalistic science, its medicine, its capital and consumer goods production, its global economy and worldwide communication. Its means of production alter profoundly the conditions of life in these cultures. Rich and poor, elite and masses, town and country, all crystallise into structures which partake of traditional social structures in various modifications and to varying degrees. Those who only see, or only wish to see, these developments may speak optimistically of 'one world' or of the rise of a 'world culture'. Yet the ties between the old cultures of the Third World - their languages, history, religious, values, and standards of living and technological civilisation, with its cognitive, instrumental rationality and its pragmatic, secular values, are not formed without cost. To put it bluntly, the surrender of traditional cultures in favour of functional adaptation to a system of powerful industrial states, does not proceed in the manner perhaps imagined by some politicians and economists who were nourished on the optimism of post-World War II economic expansion and the euphoria accompanying the achievement of political sovereignty by former colonies.

In the countries of the Third World, innumerable projects have been carried out on the initiative and with the technical and financial help of international institutions, governments of industrial states, private monopolies, or by charitable organisations. Many of these projects either failed or were only marginally successful. Some of them have created mere branch offices of a worldwide industrial and commercial network which have been of little use to the local population. As Dahrendorf rightly notes, the 'trickledown effect' from the elites into the population has remained negligible. The more such projects were intended to benefit the masses, the less they succeeded, if they did not fail altogether - at the latest when the 'experts' returned home.

During the so called second development decade of the 1970 s, the view gradually gained ground among politicians and managers of development capital that the main reason for the failure of development projects had been, apart from political and economic ones, that the task of mastering the cultural differences between industrial and recipient nations had been inadequately solved. The projects were undertaken without adequate analysis of local and regional traditions or natural, social and cultural needs; without appropriate participation of the local inhabitants; without attempting to familiarise project managers with the given social situation; and without adequate deliberation about the effects of the projects or their long range future. 
Thanks to such insights, if not only to them, special attention has since been devoted to the satisfaction of only the most urgent, so called basic needs of the Third World. On this elementary level, it is argued, the importance of the affected culture and thus the problem of cultural differences would disappear. The necessity of many practical measures notwithstanding, the fact that many representatives of the Third World see this set of priorities as, once again, disqualifying their peoples along the lines of "modern technology for the West and Gandhism for the Third World' [Nandy 1981:101], sheds doubt on the validity of the assumptions that underlie them.

\section{The Universal Responsibility of Reason}

Here indeed the politicians, economic specialists, and practitioners, including educationists, who deal with the Third World have run up against a dilemma. It must be asked whether the pragmatic steps they recommend to achieve a modus vivendi really do justice to all nations' needs; and further, whether these steps will assist in the breakthrough of a universal reason capable of wresting the planet from the mercy of economic, political and military interests governed by particularist thinking. Studies in evolutionary theory, along with the empirical research of cultural anthropologists, sociologists and psychologists, take on great significance in this connection. Though a detailed account of their findings cannot be given here, the following points may be made.

\section{The cultural tradition which led to technological civilisation in the 'First World'}

The break in European culture which, as Weizsäcker noted, came about as technological civilisation gained predominance from the end of the eighteenth century, is after all the consequence of that culture's particular development since the Middle Ages, and these events in turn were built upon Jewish, Hellenistic and Christian traditions. We may therefore question Weizsäcker's assumption that 'the intellectual and material building blocks of technological civilisation cannot be reproduced within decades by a culture shaped by a different history, though this can be achieved over a longer period of time' [1976:16]. Evidently, they are already being reproduced, but at what cost and sacrifice? As Habermas has argued, the 'occidental world view' with its claim to universality stands opposed to a 'mythic world view' in primordial societies, which 'is hardly able to provide orientation for rational action in our sense of the term' [1981:73]. For an emancipated [world] society of rational communication to come into being, Habermas posited the need for dispersing egocentrically conceived visions of the world and rationalising our modes of existence in the direction of free discourse between cultures.
We can scarcely describe the 'modernisation' of many Third World societies as having been 'rational' in Habermas' sense. It is of note here that this author's distinction between occidental and mythical world views points to the radical difference between that break in European cultural history cited by Weizsäcker, since when Europeans have pursued, as Max Weber put it, the 'demythification of the world', and the collision of technological civilisation with the differently formed cultures of the Third World, which have been subjected to this civilisation with little attempt to link it meaningfully with either their modes of existence or their world view.

\section{Multiplicity of Third World cultures and their traditions}

What Third World cultures do such policy makers as Brandt and such philosophers as Weizsäcker have in mind, when they state that "cultural identity should be maintained', or when they warn against the danger of 'cultural levelling"? The stereotyped opposition of the First World (Europe) to the primordial world is an artificial model useful mainly to clarify problems in theory. Empirical studies only rarely come across relatively small nests of surviving primordial cultures, but a variety of cultures of the most highly individuated nature - strikingly archaic cultures such as those of certain Polynesian islands, or in isolated regions of Black Africa, or among the Amazon Indians of Brazil - exist alongside millenia-old high cultures such as those of China and India.

The lands shaped by Islamic tradition exhibit many tendencies, from fundamentalism to enlightened cosmopolitanism. What do mode of existence and world view mean in each of these different cultures, and which orientation can be said to be rational? We need to remind ourselves again and again that China, India, and the Islamic countries have long and significant traditions in natural science and technology. As Rajni Kothari, Chairman of the Indian Council of Social Science, wrote: 'What is common to all of them is to think of science and technology as basically a search for truth, as a means of self-realisation and self-control, not as a means of bringing anything under domination, including nature' [1981:81]

Latin America is a continent of white colonisers, Roman Catholic in origin, who largely destroyed the ancient cultures they found there. Notwithstanding their partial mixing with the Incas, Aztecs and other Indian peoples, they remained the elite and thus still stand more strongly in the European tradition than peoples of the regions just mentioned.

All of the cultures mentioned - except for a very few virgin areas - are already under the influence of 
technological civilisation. And the world view of this civilisation is one in which 'science and technology are but means for steamrolling almost the entire world into a uniformity, reducing its rich diversity to a predictable and predetermined state' [Kothari 1981]. Cities are becoming the focal points both of 'modernisation' and of impoverishment. Wherever capital accumulates and industrialisation proceeds far enough, 'threshold countries' emerge, technically prepared to join the circle of industrialised countries despite the poverty and underprivileged situation of the masses of their people. If a country's leap onto the capitalist train falls short, it is overtaken by famine against which its subsistence economy is helpless.

Almost all of these national ethnic groups and cultures exhibit historical discontinuities not unlike those of European nations. As V. S. Naipaul wrote of India in 1977:

India in the late twentieth century still seems so much itself, so rooted in its own civilisation, that it takes time to understand that its independence has meant more than the going away of the British; that the India to which independence came was a land of far older defeat; that the purely Indian past died a long time ago [1977:8].

Naipaul is convinced that the people of India, after centuries of foreign rule, while still united by their traditions and world view - hierarchical, cruel, impoverished - are nevertheless a 'wounded civilisation'; and that particularly since the minimal success of Gandhi's attempt to renew village cultural life, India is a land without a vision of regeneration. Can anything more positive be said about other cultures? Have the cultures of Black Africa, thanks to centuries of colonial rule, not also become "wounded civilisations' whose regeneration and accommodation to western culture and technological civilisation seems nowhere to be occurring, not even in Senghor's négritude or Nyerere's ujamaa socialism? And, in the countries of Central and South America, has there really been an assimilation and accommodation between the conquerors and the original inhabitants like that envisaged in his murals by the great painter of the Mexican Revolution, José Clemente Orozco?

If a transformation of the maxims of development policy and the theories of social philosophy into practical cooperative efforts between industrial and developing countries is to come about at all, much more intensive study and more empathetic understanding of these foreign cultures is necessary than many who deal with them on a daily basis have shown, even people who are active in the educational systems or in research in the Third World countries.
Cultural identity The statement that it is necessary to maintain cultural identities is not really adequate to describe the challenge which both industrial and developing countries must face when dealing with one another. 'Cultural identity' defines less a static condition than a process, in the course of which a society's mode of existence and value system develop more or less consistently over a long period of time, and not late in history in interaction with other societies. The commitment to maintaining cultural identities in Third World countries should not disguise the reality that accommodation is necessary on both sides, and that consequently the industrialised nations will also have to submit to it.

If the Third World is to be readied not only for an assimilation of technological civilisation but also to participate in the development of a modern understanding of the world such as that conceived by von Weizsäcker, in terms of universalistic reason, and by Habermas, in terms of 'communicative reality', then every egocentric - or ethnocentric - view of the world will have to be dispensed with. This demand would affect both more or less explicitly mythical conceptions of the world, and the conception of modern capitalist societies, distorted as it is by having 'devalued the substance of its traditions' (including, we may add, its 'myths'!) and 'by its subordination to the imperatives of a one-sided rationality limited to cognitive and instrumental functions' - or, to put it more precisely, a world view distorted by having allowed the compulsions of a system to encroach on daily life [Habermas 1981:I 112, II 489 ff].

But is not all of this still mere theory? Is not the damage to many old cultures far too advanced, and has not the poverty of many peoples reached such a level, that they scarcely can concern themselves now with the dangers of technological civilisation, let alone with questions of mutual accommodation in the sense just described? Ashis Nandy of the Center for the Study of Developing Societies, New Delhi, writes the following about contemporary Third World societies:

Societies resist being taught; they prefer to learn on their own. It is improbable that the western experience will deter us from further mechanising man and investing the machine with greater charisma. The West's illnesses created by the machine are too distant, its gains from technology, measured in terms of power and wealth, too obvious. Our suffering due to dependence and poverty, on the other hand, seems real and immediate, and the dangers posed by modern technology in the Third World seem abstract and hypothetical [1981:102].

To conclude this part of the discussion, we have sought: 
- to show the problems involved in the collision between industrial and Third World cultures, and their fundamental differences from upheavals in European historical development;

- at least to suggest, contrary to widespread simplifications, the extremely differentiated reality of Third World cultures, which for the most part are highly developed, if in many respects wounded by events in their own history and by the impact of technological civilisation;

- to disclose the misuse of the concept of 'cultural identity' as an ideologically one-sided slogan, and to indicate thereby the continuing importance and responsibility of the industrial countries in their communications with the Third World.

If the conditions which threaten the peace - and indeed the very existence - of 'spaceship earth' are to be overcome, if knowledge and power are to be subordinated to reason, then the industrial states will first have to question the assumptions on which their own cultures, their science, their economies, and their power politics are based, and moreover be willing to submit to the analyses and critiques of Third World nations. Furthermore, the industrial countries will have to show that they can create the objective conditions which make self-correction and communication possible. Deserving special attention in this regard is von Weizsäcker's pointed question, 'Are we moving towards an ascetic world culture?' [1978a], as well as Erhard Eppler's critique of the ostensibly compulsive and irreversible nature of economic growth and his ideas for Pathways out of Danger [1981]. A demonstration of reasonable ways to deal with knowledge, power, the world economy and technology, may be the only chance we have to spare the Third World from the pitfalls of industrial civilisation Ashis Nandy has described.

\section{The Significance of Different Cognitive Styles}

By some short, very general remarks I should like to point to the fact that differences between national cultures in the Northern part of the world (Europe, the US), as well as between regional and national cultures in the South, lead to - what 1 would call - different cognitive styles and different approaches in research. If we speak of research in Britain or in the Netherlands we usually expect a rather inductive approach: it starts from some kind of familiarity with the Anglophone or, respectively, Dutch speaking Third World countries, derived from colonial experience and continuing communication. This provides the base for careful collection and interpretation of datia. It results in accurate, thoughtful descriptions based on evidence.
A merican researchers very often seem to be somewhat more naïve. Why can the whole world not gain an American view of the world? They usually stress the collection of quantifiable data and the processing of them by statistical methods: a style of research which seems to be spreading all over the world at present, a positivistic approach which is sometimes called a 'classic' paradigm. Many German researchers tend to stress the need for more than merely middle range theories; they work in a rather deductive way and, due to German history since 1918, most of them lack international experience compared with scholars and research institutions from the previously mentioned countries.

Before we come to cognitive styles in Third World countries, let me add some further distinctions. Since the end of the 1960s, it is generally recogised that social, and particularly educational, research in countries not our own needs intense empathy on the part of the researcher for the foreign people he or she will be dealing with. Their customs and further cultural traditions, their social and economic situation, provide important background information and demand careful understanding and adaptation. Usually, empathy will be correlated with the scientific discipline to which the researcher belongs. Think of the professional attitude of a cultural anthropologist in comparison with the attitudes of an average economist or even an engineer working at an institution of higher education in the Third World. National and disciplinary cognitive style will lead to different sensitivity in the particular research task; and the concept or notion of the latter may be linked more or less strongly with the culture concerned or under review. The stronger the sensitivity, the more difficult become generalisations.

In turning to cognitive styles in Third World countries I do not want to stress their cultural differences once more but I should like to make two specific points:

- more or less all of these countries have undergone and continue to undergo processes of modernisation which in many respects are equal to 'westernisation' according to their specific relations with individual western countries. The British left their impact in Anglophone, the French in Francophone, regions and so did the Spanish, the Portuguese, the Dutch in their former colonies. Even the US through its immense economic power and very important role in modern higher education and research is imprinting many institutions and people with its own stamp;

- in all countries, westernisation is affecting the urban elites far more than the common people. Traditional social structures are overlaid with antagonistic modern social classes. In these countries social scientists usually come from traditional elites. 
They are socialised partly by their home culture, partly by their education and training in one of the 'Northern' countries, be it the US, Britain, the Netherlands, France or in far less frequent cases, Germany. The more the scientists adapt to the cognitive style of their reference country and st rive for acceptance as being equal to researchers there, the more many of them lose contact with common people in their own country and interest in their concerns. With all respect for colleagues from these countries, I sometimes gain the impression of a paradoxical situation. There is a growing number of western social scientists who try to understand indigenous cultures in the Third World. They direct their attention to the problems of the masses of people at the base of those countries. At the same time scientists who grew up there are tempted to devote their energy primarily to research tasks and methods which would earn them respect in the Northern part of the world, many of them joining the stream of the braindrain.

The weights of influence mentioned in the first point and the orientation remarked in the second can mislead even conscientious researchers into misunderstanding the cultures or minds of the educational systems they are investigating. They need to be openly taken into account, if educational research is to assist cross-country understanding without promoting the levelling of cultures.

\footnotetext{
The first two sections are adapted from: D. Goldschmidt, 1982, 'Raumschiff Erde - Nachdenken uber Wege in der Gefahr', in K. M. Meyer-Abich (ed), Physik, Philosophie und Politik: Festschrift für C. F. v. Weizsäcker, Carl Hanser Verlag, Munich, pp 119-33.
}

\section{References and bibliography}

Brandt Commission, 1980, North-South: a programme for survival, report of the Independent Commission on International Development Issues, Introduction by Willy Brandt, Pan Books, London

-1983, Common Crisis North-South: cooperation for world recovery, Pan Books, London

Council on Environmental Quality and US Department of State, 1980, The Global 2000 Reporl to the President, US Government Printing Office, Washington

- 1981, Global Future: time to act, US Government Printing Office, Washington

Dahrendorf, R., 1980, 'Wider Romantik und Mythos - die Unterschiede zwischen armen und reichen Staaten wachsen', Die Zeil, 8 August

Eppler, E., 1981, Wege aus der Gefahr, Reinbek b. Hamburg

Habermas, J., 1981, Theorie des kommunikativen Handelns, Bd 1: 'Handlungsrationalität und gesellschaftliche Rationalisierung', Bd 2: 'Zur Kritik der funktionalist ischen Vernunft', Frankfurt/M

Kothari, R., 1981, 'The cultural roots of another development', Development, vol 3/4, pp 80-2

Naipaul, V. S., 1977, India a Wounded Civilisarion, André Deutsch, London

Nandy, A., 1981, 'Dialogue on the traditions of technology', Developmenı, vol 3/4, pp 98-105

von Weizäcker, C. F., 1963, Bedingungen des Friedens, Göttingen

-1976, Wege in der Gefahr - eine Studie über Wirlschaft, Gesellschaft und Kriegsverhülung, Munich, Vienna

- 1978. The Politics of Perils: economics, sociely and the prevention of war, Seabury Press, New York

- 1978a, 'Gehen wir einer asket ischen Welt kultur ent gegen?' in Ders., Delulichkeil - Beirräge zu politischen und religiösen Gegenwartsfragen, Munich, Vienna 